ORIGINAL ARTICLE

\title{
EDUCATIONAL INTERVENTION ON SCHOLAR'S \\ KNOWLEDGE REGARDING SCHISTOSOMIASIS \\ IN A RIVERSIDE COMMUNITY, NORTHEASTERN BRAZIL
}

Jonathan da Fraga Santana ${ }^{1 s}$, Lucas Martins da Silva ${ }^{1 s}$, Filipe Valdino Ferreira Pereiral, Bruno Ferreira Amorim ${ }^{2}$, Paulo Vitor Pimentel ${ }^{2}$, Mariana do Rosário Souza ${ }^{3,4}$, Caique Jordan Nunes Ribeiro ${ }^{5}$, Allan Dantas dos Santos ${ }^{5}$, Priscila Lima dos Santos ${ }^{3,6,7}$, Débora dos Santos Tavares ${ }^{6}$ and Márcio BezerraSantos $^{3,4,7,8}$

\section{ABSTRACT}

Schistosomiasis is still a serious public health concern in Brazil and Sergipe State presents the highest prevalence rate of the disease. Brazil implemented the Schistosomiasis Control Program (PCE) with several strategies to control the disease, including health education actions in endemic areas. Herein, we assessed the impact of an educational intervention on knowledge concerning schistosomiasis in students from a riverside village of Sergipe, Northeastern Brazil. The study was carried out in 3 phases. 1) A questionnaire was applied to assess the students' knowledge about the biological, clinical, and epidemiological aspects of schistosomiasis mansoni (pre-test). 2) Next, an educational intervention was conducted. Pamphlets about schistosomiasis were distributed to the entire school community, who were then invited to a lecture. 3) A post-test was performed using the questionnaire to assess acquired knowledge. 151 elementary school students were interviewed. $2.6 \%$ of the pre-test students and $4.3 \%$ of the post-test group had already been diagnosed with schistosomiasis. In the pre-test, only $24.5 \%$ knew the cause of the disease and $48.3 \%$ the transmission sites. In the post-test, $74.3 \%$

1. Universidade Federal de Sergipe (UFS), Department of Pharmacy, Lagarto, Sergipe, Brazil.

2. UFS, Department of Medicine, Lagarto, Sergipe, Brazil.

3. UFS, Health Science Graduate Program, Aracaju, Sergipe, Brazil.

4. UFS, Parasitic Biology Graduate Program, Aracaju, Sergipe, Brazil.

5. UFS, Department of Nursing of Lagarto, Lagarto, Sergipe, Brazil.

6. UFS, Department of Health Education, Lagarto, Sergipe, Brazil.

7. UFS, Immunology and Molecular Biology Laboratory, University Hospital, Aracaju, Sergipe, Brazil.

8. UFS, Department of Morphology, Aracaju, Sergipe, Brazil.

$\S$. JFS and LMS share the first authorship.

Jonathan da Fraga Santana: https://orcid.org/0000-0003-4349-551X; Lucas Martins da Silva: https://orcid.org/0000-0001-94681967; Filipe Valdino Ferreira Pereira: https://orcid.org/0000-0001-6339-3292; Bruno Ferreira Amorim: https://orcid.org/00000002-2581-2983; Paulo Vítor Pimentel: https://orcid.org/0000-0002-0497-5628; Mariana do Rosário Souza: https://orcid.org/00000002-3139-8483; Caique Jordan Nunes Ribeiro: https://orcid.org/0000-0001-9767-3938; Allan Dantas dos Santos: https://orcid. org/0000-0002-6529-1887; Priscila Lima dos Santos: https://orcid.org/0000-0002-8863-5718; Débora dos Santos Tavares: https:// orcid.org/0000-0001-5452-0771; Márcio Bezerra-Santos: https://orcid.org/0000-0001-9962-6537

Corresponding author: Márcio Bezerra-Santos, Rua Claudio Batista, 505, CEP: 49060-025 Aracaju Sergipe, Brasil. E-mail: marciobezerra.ufs@outlook.com 
$(\mathrm{OR}=8.9 ; \mathrm{p}$-value $<0.0001)$ knew the etiology and $77.1 \%$ the possible transmission sites $(\mathrm{OR}=$ 3.6; p-value $<0.0001$ ). There was also significant improvement in knowledge regarding signs, symptoms and prophylactic measures. Most students were unaware of the risk of reinfection by Schistosoma mansoni after treatment. The educational intervention proved quite effective in increasing information on schistosomiasis. These results reinforce the importance of health education as an auxiliary tool in the control of schistosomiasis.

KEY WORDS: Schistosomiasis mansoni; health education; schoolchildren; neglected tropical diseases; Brazil.

\section{INTRODUCTION}

Schistosomiasis is a neglected tropical parasitic disease, which mainly affects people aged 6 to 30 years. It is endemic in Brazil and also in several countries located in Asia, Africa and Latin America, especially in peripheral regions with poor basic sanitation and water supply infrastructure (Abera et al., 2013; Saucha et al., 2015; WHO, 2018). World Health Organization (WHO) and the World Health Assembly classified this pathology as a serious public health problem and planned its eradication by 2030, using mass drug administration (MDA). Nevertheless, according to data from the WHO, today about 708 million people around the world are at risk of infection with Schistosoma sp. and more than 240 million are infected (WHO, 2018). These epidemiological data clearly show that this goal is still far from being attained. In Brazil, the most affected country in the Americas, schistosomiasis has been considered a public health problem for decades. Currently, it is estimated that about 1.5 million people are infected by the parasite in the country (Brazil, 2014; Katz, 2018). Schistosomiasis mansoni is present in 19 states, but more than $95 \%$ of cases are in the Northeast and Southeast regions of Brazil (Brasil, 2014; Paz et al., 2020). In the Northeast region, the States of Sergipe, Alagoas, and Pernambuco present the highest rates of mortality and positivity for $S$. mansoni (dos Santos et al., 2016; Santos et al., 2017a; Katz, 2018; Paz et al., 2020; Silva da Paz et al., 2021).

In 1975, the Special Schistosomiasis Control Program (PECE) was created to monitor the disease in Brazil and replaced in the 80 s by the Schistosomiasis Control Program (PCE). The actions attributed to endemic municipalities were: coproscopic diagnosis, treatment of the infected individuals, control of Biomphalaria snails, effective basic sanitation policies, and health education actions (Brazil, 2014; Katz, 2018). Through a mass chemotherapy treatment for schistosomiasis in endemic areas, a reduction in the number of patients with the hepatosplenic form of the disease was noted and, therefore, a decrease in mortality rates (Paz et al., 2020). Conversely, in 1999, health PCE actions were decentralized and the competences shared between states and municipalities, probably affecting the effectiveness of the program in poor states (Favre et al., 2001; Paz et al., 2020). Some studies 
that evaluated PCE in endemic areas also highlighted a number of issues regarding program administration, such as inadequate epidemiological and environmental surveillance, laboratory analyses, and health education actions (do Amaral et al., 2006; Costa et al., 2017).

The highest prevalence rates of schistosomiasis are found in populations suffering from greater economic and social vulnerability, with precarious environmental and hygiene infrastructure, lack of basic sanitation and low education levels (Rollemberg et al., 2011; Gazzinelli et al., 2012; Vidal et al., 2012; Ruiz-Díaz et al., 2017). In this context, Santos and colleagues (Santos et al., 2012) highlight the importance of teaching practices and pedagogical actions as basic tools to upgrade prophylactic knowledge of parasitic diseases and other illnesses. As a result, prevalence can be reduced through health education actions, ideally involving the school, the community and the family in all stages and strategies for the control of parasite infection and health promotion (Barry et al., 1999; Ferreira \& Andrade, 2005; Bieri et al., 2012; Santos et al., 2012; Paixão et al., 2019; Favre et al., 2021).

Notably, the State of Sergipe has municipalities presenting high endemicity for schistosomiasis and also significant socioeconomic and health disparities (dos Santos et al., 2016; Lima et al., 2019; Santos et al., 2019). Among these, the municipality of Lagarto, and Jenipapo village (study area), present a high schistosomiasis positivity rate. The Zoonoses Control Center (CCZ), through a PCE survey using the Kato-Katz method, showed that the prevalence of individuals infected with $S$. mansoni in this village was $11.2 \%$, in 2017. In a more recent survey carried out in 2018, the positivity rate was $20.8 \%$, tending to increase (Brazil, 2020). For this reason, the population's effective information on schistosomiasis, attitude, and behavior, especially those from vulnerable areas, may contribute to the strategic planning of public policies aimed at surveillance, diagnosis, control, and prevention of the disease. In this study, we evaluated the impact of an educational intervention on student knowledge regarding routes of transmission, clinical complications, and prevention of schistosomiasis in a riverside community in the municipality of Lagarto (Sergipe State), considered an endemic area in Northeast Brazil.

\section{MATERIAL AND METHODS}

\section{Ethical Considerations}

This study followed the ethical principles of research involving human beings established by Resolution 466/2012 of the National Health Council (CNS) and the Declaration of Helsinki. The project was approved by the Research Ethics Committee of the Federal University of Sergipe (CAAE: 92576818.0.0000.5546). Those responsible for the students who agreed to participate in the study signed the Free and Informed Consent Form (ICF). 


\section{Study Design and Area}

This is an epidemiological and cross-sectional study with descriptiveanalytical characteristics: there are two observation moments, before and after an educational intervention, both verifying knowledge of schistosomiasis. The research was carried out in a village called Jenipapo, located in the municipality of Lagarto, in the south-central region of the State of Sergipe (Figure 1A-B). The municipality of Lagarto covers $968,921 \mathrm{~km}^{2}$ with an estimated population of 104,408 inhabitants in 2019 (IBGE, 2019). It is the third most populous municipality of Sergipe, presenting a population density of 97.8 inhabitants $/ \mathrm{km}^{2}$ and located $45.2 \mathrm{~km}$ (in a straight line) from the capital of Sergipe, Aracaju. Jenipapo village is located in a transition area between the tropical and semiarid climates. The village is crossed by the Vaza-Barris river (the largest freshwater river in the Municipality) and is close to the Quirino river (IBGE, 2019). Likewise, information from the Zoonoses Control Center (CCZ), collected in one of the PCE actions, show that both rivers presented species of Biomphalaria sp. (Brazil, 2020).

\section{Study Sample and Limitations}

This study included schoolchildren living in Jenipapo, who agreed to participate in the study and answered the survey questionnaire. For the intervention process, 6th to the 9th grade elementary school students, from the municipal publicschool system, were selected. The sample herein was defined by convenience and part of the students, whose teachers did not authorize participation of their classes in the intervention, acted as limiting factors.

\section{Data Collection and Educational Intervention}

Data were collected based on a questionnaire adapted from Lima (Lima, 2015). The questionnaire consisted of objective unscored questions, and aimed to analyze the frequencies of socio-demographic characteristics and the student's knowledge of schistosomiasis regarding biological and clinical aspects, epidemiology, routes of transmission and strategies for disease prevention.

The study was carried out in three moments:

1) Pre-test. Initially, all students, who agreed to participate in the research, were asked to answer a questionnaire (containing 20 questions) during class time and with no time limit for answering. The questions were grouped in three categories: A) personal characteristics of the students (gender, age, if they had already been diagnosed for schistosomiasis and if they were treated for the infection); B) students' knowledge of the etiology and clinical aspects of schistosomiasis (signs and symptoms); and C) students' knowledge of the diagnosis, treatment, and prophylaxis of schistosomiasis. In this phase, 151 students answered the questionnaire. 


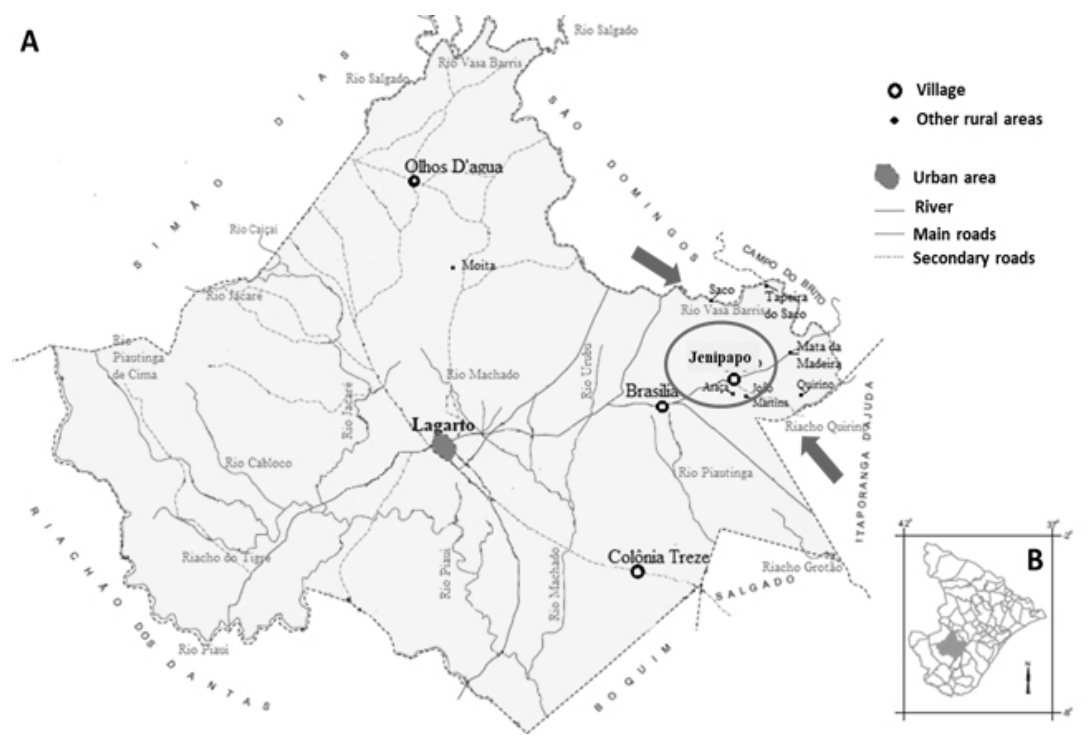

Figure 1. A) Map of the Lagarto municipality highlighting Jenipapo village. The hydrographic and road network of the municipality of Lagarto/SE are also shown. B) Map of the State of Sergipe, highlighted in gray for the municipality of Lagarto. The ellipse indicates the location of the study area, the riverside community of Jenipapo village. The arrows indicate the two main rivers that cross the village: Vaza-Barris and Quirino rivers.

2) Educational intervention. After applying the questionnaire (same day), we carried out an educational intervention in the school. Pamphlets containing information about schistosomiasis were distributed among students, teachers, and school employees. Additionally, the entire school community was invited and most of them participated in a lecture. This focused on the main aspects of schistosomiasis, particularly transmission forms, epidemiological situation of the disease in the State of Sergipe and in Jenipapo village itself, clinical complications, and prophylactic measures. Only one teacher did not agree to participate in the event. The lecture was given by the authors of the study using a media projector and slides containing information and images of the disease, produced in PowerPoint software (Windows/2017).

3) Post-test. One week after that educational intervention, the questionnaire was reapplied. In this phase, 70 students answered the questionnaire. The purpose being to compare the knowledge of students before and after the educational intervention. Unfortunately, some students did not agree to answer the questionnaire in the post-test and one teacher did not allow his class to participate this time. Thereby, we consider this a limitation in the study. 
The collected data were organized in spreadsheets, tabulated, and stored in Microsoft Excel software, 2016 (Microsoft Corporation; Redmond, WA, USA). The comparison of the variables analyzed in the pre and post-test was performed using the chi-square test for equality $(\chi 2)$. The results were considered statistically significant if $p$-value $<0.05$. Statistical analysis was performed using the GraphPad Prism software, version 8.0.

\section{RESULTS}

151 students answered the pre-test and participated in the health education action and 70 agreed to answer the questionnaire a second time (post-test), one week after the intervention actions (Table 1). There was no difference regarding the average age between the pre and post-test groups, 13.8 and 14.6 years of age, respectively. Most participants were female both in the pre and post-test, 58.9 and $70 \%$, respectively. $2.7 \%$ of the pre-test students and $4.3 \%$ of the post-test group had already been diagnosed with schistosomiasis. Surprisingly, $25 \%$ of those that tested positive for schistosomiasis in the pretest moment (as reported) stated that they had not been treated for the disease.

Table 1. Characteristics of the students in Jenipapo village, municipality of Lagarto, Northeast Brazil, 2020.

\begin{tabular}{|c|c|c|c|}
\hline Variables & & $\begin{array}{l}\text { Pre-Test } \\
(\mathrm{n}=151)\end{array}$ & $\begin{array}{l}\text { Post-Test } \\
(\mathrm{n}=70)\end{array}$ \\
\hline \multirow[t]{2}{*}{ Age (years) } & (variation) & $10-20$ & $11-19$ \\
\hline & medium $\pm \mathrm{SD}$ & $13.8 \pm 1.47$ & $14.6 \pm 1.41$ \\
\hline \multirow[t]{2}{*}{ Gender n $(\%)$} & male & $62(41.1)$ & $21(30)$ \\
\hline & female & $89(58.9)$ & $49(70)$ \\
\hline \multirow[t]{2}{*}{ Past diagnosis for SM n (\%) } & yes & $4(2.6)$ & $3(4.3)$ \\
\hline & no & $147(97.4)$ & $67(95.7)$ \\
\hline \multirow[t]{2}{*}{ Past treatment for SM n $(\%)$} & yes & $3(75)$ & $3(100)$ \\
\hline & no & $1(25)$ & $0(0.0)$ \\
\hline
\end{tabular}

$\mathrm{n}=$ sample number; $\mathrm{SD}=$ Standard deviation; $\mathrm{SM}=$ Schistosomiasis mansoni. 
Table 2 presents data on knowledge of the etiological and clinical aspects of schistosomiasis. There was a significant improvement in the students' knowledge after the educational intervention, for all items evaluated in this category. In the pre-test, only $24.5 \%$ of students said they knew the cause of the disease, $52.3 \%$ knew the route of transmission and $48.3 \%$ the places where the disease could be transmitted. In the post-test, $74.3 \%(\mathrm{OR}=$ 8.9; p-value $<0.0001)$ knew the disease etiology, 84.3\% (OR= 4.9; p-value $<0.0001)$ the form of transmission and $77.1 \%$ (OR $=3.6$; $p$-value $<0.0001)$ the place of transmission. Likewise, there were also significant improvements concerning knowledge regarding the route of parasite entry [pre-test $(19.9 \%)$ vs. post-test $(58.6 \%$; OR $=5.7$; $\mathrm{p}$-value $<0.0001)]$ and schistosomiasis signs and symptoms, exhibiting the highest percentage difference and odds ratio ( $7.3 \%$ vs. $58.6 \%$; OR $=18.0$; -value $<0.0001)$.

Table 3 shows the results related to knowledge regarding treatment and prophylaxis of schistosomiasis. Similarly to the previous data, a significant increase was noted in the students' knowledge regarding the various measures for preventing the disease $(13.9 \%$ vs. $62.9 \%$; OR= 10.5 ; p-value $<0.0001)$ and risk of reinfection after treatment $(33.1 \%$ vs. $66.7 \%$; OR $=4.0 ; p$-value $<0.0001)$. Despite the significant improvement in knowledge on the treatment of the disease in the post-test $(1.3 \% \mathrm{vs}$. $12.5 \% ; \mathrm{OR}=9.3 ; \mathrm{p}$-value $=0.002$ ), the percentage remained low.

When asked about how the government could help to control the disease, in the pre-test $56 \%$ of students said they did not know. In the posttest, this percentage dropped to $9.1 \%$. The control measure "improvements in the basic sanitation network" stands out, which went from $12 \%$ to $59.1 \%$ $(\mathrm{p}$-value $=0.001)$.

Another result worth mentioning refers to the methods of schistosomiasis control by the local population. In the pre-test, no student mentioned the option "not to defecate near rivers". However, in the posttest, $47.8 \%$ of the students chose that option ( $\mathrm{p}$-value $=0.0014)$. In addition, when they answered the questionnaire for the first time, $39.3 \%$ believed that not accumulating standing water would be an effective measure to prevent schistosomiasis. In the post-test, this percentage dropped to $17.4 \%$.

It is also necessary to highlight the increase in student knowledge after the educational intervention regarding the signs and symptoms in a patient with schistosomiasis (Figure 2A-B). In the pre-test, almost half (46.2\%) of them referred to the growth of the abdomen ("big belly") (Figure 2A). Fever, diarrhea, and headache, each mentioned by $15.4 \%$. In the post-test, the students were able to report a much greater variety of signs and symptoms such as fever $(24.4 \%)$, headache $(18.6 \%)$, diarrhea (10.5\%), vomiting $(8.1 \%)$, nausea $(6.9 \%)$, enlarged liver $(5.8 \%)$ or spleen $(3.5 \%)$, and ascites $(4.6 \%)$ (Figure 2B). 
Table 2. Data on students' knowledge of the etiology and clinical aspects of schistosomiasis.

\begin{tabular}{|c|c|c|c|c|c|c|}
\hline \multicolumn{2}{|c|}{$\begin{array}{l}\text { Schistosomiasis (Etiology and } \\
\text { Clinical Aspects) }\end{array}$} & \multirow{2}{*}{$\begin{array}{l}\text { Pre-Test } \\
(\mathrm{n}=151)\end{array}$} & \multirow{2}{*}{$\begin{array}{l}\text { Post-Test } \\
(\mathrm{n}=70)\end{array}$} & \multirow{2}{*}{$\begin{array}{l}\text { OR } \\
8.9\end{array}$} & \multirow{2}{*}{$\begin{array}{l}\text { CI95\% } \\
1.9-4.4\end{array}$} & \multirow{2}{*}{$\begin{array}{l}\mathrm{p} \text {-value } \\
<0.0001\end{array}$} \\
\hline Do you know the cause & yes & & & & & \\
\hline & no & $114(75.5)$ & $18(25.7)$ & & & \\
\hline \multirow{2}{*}{$\begin{array}{l}\text { Do you know the mode } \\
\text { of transmission for SM? } \\
\mathrm{n}(\%)\end{array}$} & yes & $79(52.3)$ & $59(84.3)$ & 4.9 & $1.7-5.3$ & $<0.0001$ \\
\hline & no & $72(47.7)$ & $11(15.7)$ & & & \\
\hline \multirow[t]{2}{*}{$\begin{array}{l}\text { Where do you get SM? } \\
\mathrm{n}(\%)\end{array}$} & $\begin{array}{l}\text { river/ } \\
\text { streams/ } \\
\text { lagoon }\end{array}$ & $73(48.3)$ & $54(77.1)$ & 3.6 & $1.4-3.5$ & $<0.0001$ \\
\hline & $\begin{array}{l}\text { beach/ } \\
\text { pool/ } \\
\text { toilet/do } \\
\text { not know }\end{array}$ & $78(51.7)$ & $16(22.9)$ & & & \\
\hline \multirow{2}{*}{$\begin{array}{l}\text { Do you know the } \\
\text { parasite entry route in } \\
\text { the human body? n (\%) }\end{array}$} & yes & $30(19.9)$ & $41(58.6)$ & 5.7 & $1.4-2.6$ & $<0.0001$ \\
\hline & no & $121(80.1)$ & $29(41.4)$ & & & \\
\hline \multirow{2}{*}{$\begin{array}{l}\text { Do you know the } \\
\text { parasite habitat in the } \\
\text { human body? } \mathrm{n}(\%)\end{array}$} & yes & $21(13.9)$ & $28(40)$ & 4.1 & $2.12-8.0$ & $<0.0001$ \\
\hline & no & $130(86.1)$ & $42(60)$ & & & \\
\hline \multirow{2}{*}{$\begin{array}{l}\text { Do you know the signs } \\
\text { and symptoms of SM? } \\
\mathrm{n}(\%)\end{array}$} & yes & $11(7.3)$ & $41(58.6)$ & 18.0 & $8.2-39.1$ & $<0.0001$ \\
\hline & no & $140(92.7)$ & $29(41.4)$ & & & \\
\hline \multirow[t]{3}{*}{$\begin{array}{l}\text { What makes you more } \\
\text { susceptible to SM? n } \\
(\%)\end{array}$} & $\begin{array}{l}\text { contact } \\
\text { with } \\
\text { water }\end{array}$ & $6(4.0)$ & $3(4.3)$ & -- & -- & 0.001 \\
\hline & $\begin{array}{l}\text { lower } \\
\text { body } \\
\text { resistance }\end{array}$ & $57(37.7)$ & $44(62.9)$ & & & \\
\hline & $\begin{array}{l}\text { do not } \\
\text { know }\end{array}$ & $88(58.3)$ & $23(32.8)$ & & & \\
\hline
\end{tabular}

$\mathrm{n}=$ sample number; $\mathrm{OR}=$ Odds Ratio $\mathrm{CI}=$ Confidence Interval $\mathrm{SM}=$ Schistosomiasis mansoni. 
Table 3. Data on students' knowledge of the treatment and prophylaxis of Schistosomiasis.

\begin{tabular}{|c|c|c|c|c|c|c|}
\hline \multicolumn{2}{|c|}{$\begin{array}{l}\text { Schistosomiasis (Diagnosis, } \\
\text { Treatment and Prophylaxis) }\end{array}$} & \multirow{2}{*}{$\begin{array}{c}\begin{array}{c}\text { Pre-Test } \\
(\mathrm{n}=151)\end{array} \\
21(13.9)\end{array}$} & \multirow{2}{*}{$\begin{array}{l}\text { Post-Test } \\
(\mathrm{n}=70)\end{array}$} & \multirow{2}{*}{$\begin{array}{l}\text { OR } \\
10.4\end{array}$} & \multirow{2}{*}{$\begin{array}{c}\text { CI95\% } \\
5.3-20.4\end{array}$} & \multirow{2}{*}{$\begin{array}{l}\text { p-valor } \\
<0.0001\end{array}$} \\
\hline Do you know how to & yes & & & & & \\
\hline prevent SM? n (\%) & no & $130(86.1)$ & $26(37.1)$ & & & \\
\hline \multirow{2}{*}{$\begin{array}{l}\text { Do you know what } \\
\text { the treatment for SM } \\
\text { is? } \mathrm{n}(\%)\end{array}$} & yes & $2(1.3)$ & $8(12.5)$ & 9.3 & $1.1-12.1$ & 0.0022 \\
\hline & no & 149 (98.7) & $64(87.5)$ & & & \\
\hline \multirow{2}{*}{$\begin{array}{l}\text { Is it possible get sick } \\
\text { again after treatment } \\
\text { for SM? n }(\%)\end{array}$} & yes & $50(33.1)$ & $40(66.7)$ & 4.0 & $1.2-1.8$ & $<0.0001$ \\
\hline & no & $101(66.9)$ & $20(33.3)$ & & & \\
\hline \multirow[t]{2}{*}{$\begin{array}{l}\text { If yes, what is } \\
\text { the reason for the } \\
\text { recurrence? n }(\%)\end{array}$} & $\begin{array}{l}\text { new contact } \\
\text { with } \\
\text { contaminated } \\
\text { water }\end{array}$ & $6(50)$ & $17(85)$ & 0.1 & $0.1-0.9$ & 0.0493 \\
\hline & $\begin{array}{l}\text { low } \\
\text { immunity/ } \\
\text { standing } \\
\text { water/do not } \\
\text { know }\end{array}$ & $6(50)$ & $3(15)$ & & & \\
\hline \multirow{2}{*}{$\begin{array}{l}\text { Can the government } \\
\text { help to stop the } \\
\text { disease spreading? } \\
\text { n }(\%)\end{array}$} & yes & $61(40.4)$ & $31(49.2)$ & 1.5 & $0.8-2.7$ & 0.1757 \\
\hline & no & $90(59.6)$ & $32(50.8)$ & & & \\
\hline \multirow{4}{*}{$\begin{array}{l}\text { How can the } \\
\text { government control } \\
\text { the disease? n (\%) }\end{array}$} & $\begin{array}{l}\text { improve basic } \\
\text { sanitation }\end{array}$ & $3(12)$ & $13(59.1)$ & -- & -- & 0.0013 \\
\hline & $\begin{array}{l}\text { provide } \\
\text { treatment }\end{array}$ & $6(24)$ & $4(18.2)$ & & & \\
\hline & $\begin{array}{l}\text { health } \\
\text { campaigns/ } \\
\text { diagnosis }\end{array}$ & $2(8)$ & $3(13.6)$ & & & \\
\hline & do not know & $14(56)$ & $2(9.1)$ & & & \\
\hline \multirow{2}{*}{$\begin{array}{l}\text { Can the population } \\
\text { help to control the } \\
\text { disease? } \mathrm{n}(\%)\end{array}$} & yes & $68(45.0)$ & $39(61.9)$ & 1.9 & $1.1-3.6$ & 0.0353 \\
\hline & no & $83(55.0)$ & $24(38.1)$ & & & \\
\hline
\end{tabular}




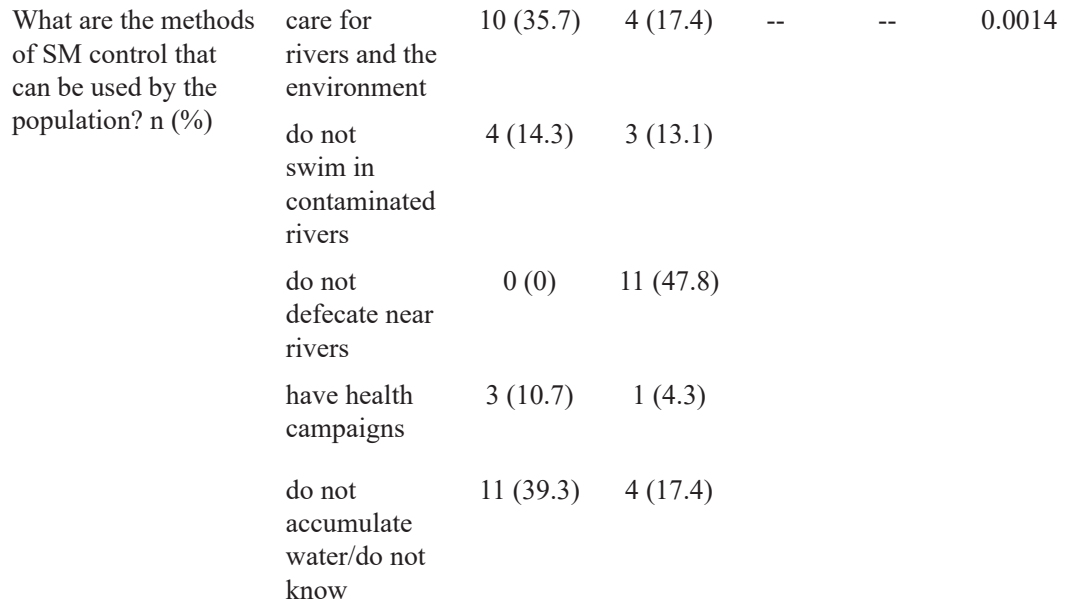

OR = Odds Ratio; $\mathrm{CI}=$ Confidence Interval; $\mathrm{SM}=$ Schistosomiasis mansoni.

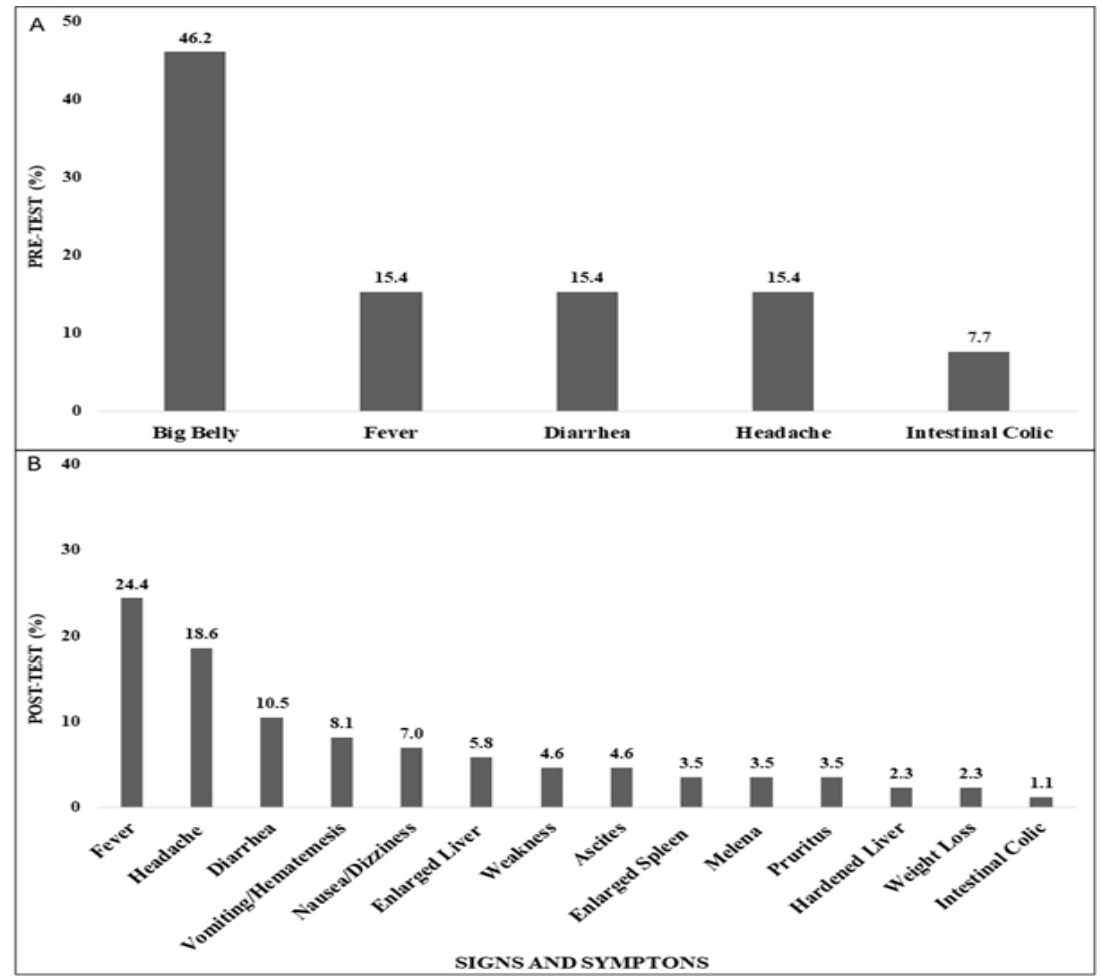

Figure 2. Percentage distribution of signs and symptoms that occur in patients with schistosomiasis, recalled by students in A) Pre-Test and B) Post-Test. 
The students were also asked about sources of information on schistosomiasis (Figure 3). The school was the item most marked in the pretest (54.3\%). In the post-test, this percentage increased to $72.1 \%$. Other sources were also mentioned: health center, media, and endemic disease agents.

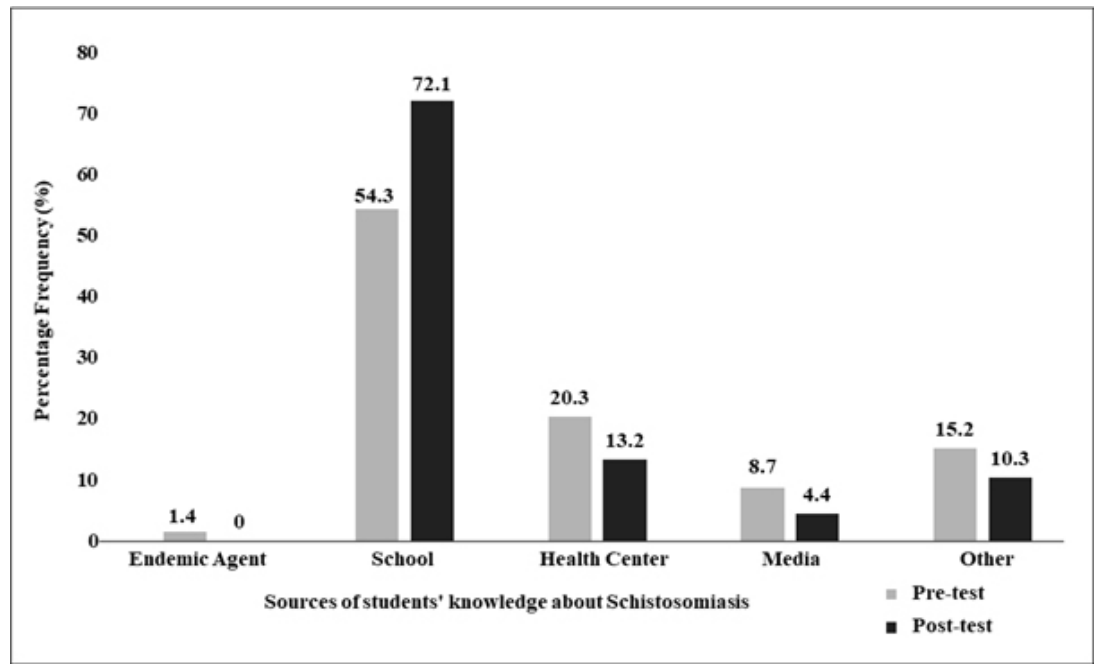

Figure 3. Percentage frequency of the main sources of knowledge about schistosomiasis, named by students in the pre and post-test.

\section{DISCUSSION}

In our study, knowledge of schistosomiasis was analyzed among schoolchildren in an area of high endemicity for the disease, before and after carrying out an educational health intervention. The results related to prior knowledge are worrying, given that most students did not present minimally satisfactory levels of information about the disease. On the other hand, the data collected after the educational intervention (distribution of informative pamphlets and a lecture on schistosomiasis) showed a significant increase in student knowledge, mainly regarding the routes of transmission and prevention measures for schistosomiasis. Altogether, the results reported herein reinforce the importance of health education as an auxiliary tool in disease control (Barry et al., 1999; Ferreira \& Andrade, 2005; Bieri et al., 2012; Santos et al., 2012; Nofal et al., 2018; Paixão et al., 2019; Hassanin et al., 2021; Favre et al., 2021).

Data reported by CCZ, through a PCE population survey, showed that the prevalence of people infected with $S$. mansoni in this village increased $86.0 \%$ between 2017 (11.2\%) and 2018 (20.8\%) (Brasil, 2020). This classifies the region as highly endemic for schistosomiasis (>15\%) (Brazil, 2014; Katz, 2018). Additionally, the region presents an extensive area covered by 
freshwater rivers, such as the Vaza-Barris River and small lagoons around the territory, with Biomphalaria snails. These places are widely used by the population for leisure or fishing and, along with inadequate waste disposal in households, preserves the disease cycle in the community and raises the risk of infection by S. mansoni (Rollemberg et al., 2011).

Interestingly, in our study less than $5 \%$ of the students stated that they had already been diagnosed with schistosomiasis. This percentage is lower than that reported in the PCE survey and probably indicates that most of the students were unaware of their real diagnosis or omitted the information. Underreporting and failure to treat positive cases are worrying features: patients may evolve with severe clinical forms of the disease and die; and asymptomatic carriers continue to eliminate eggs in feces, contaminating water collection points and maintaining the chain of disease transmission in the community (Favre et al., 2015; Lima, 2015; Santos et al., 2017a).

The educational intervention increased student knowledge of the signs and symptoms of schistosomiasis. In the pre-test, almost half mentioned the growth of the abdomen as the main characteristic of the disease. While in the post-test, the students managed to point out a much greater variety of signs and symptoms such as diarrhea, vomiting, and enlarged liver and spleen, ascites, and weight loss (chronic phase). The recognition of signs and symptoms of the disease can result in a speedier search for medical care. Likewise, diagnosis of the disease at an earlier stage can reduce the likelihood of severe illness and death (Santos et al., 2017b; King et al., 2020).

Although health education is one of the actions recommended by the PCE, none of the participants reported previous actions regarding schistosomiasis in school. We can conjecture herein that the program does not develop health education actions in this school, and perhaps even in the village. Notably, the PCE preferably seeks to carry out diagnostic inquiries, treatment of cases, and collecting Biomphalaria sp. Currently, school or community-based MDA using praziquantel is the major control strategy for schistosomiasis (de Melo et al., 2014; Favre et al., 2015).

Most students were also unaware that there is a risk of reinfection by the parasite after treatment for schistosomiasis. Some authors have shown that cases of reinfection occur in populations that received mass treatment and in those where the administration of the drug depended on the rate of positivity (Assefa et al., 2013; Favre et al., 2015; Lima, 2015). In Ethiopia, Assefa and colleagues (2013) showed that $23.8 \%$ of the studied population were reinfected three months after treatment with praziquantel. Lima (2015) identified a $21.6 \%$ reinfection rate by $S$. mansoni among students after one year of treatment. Similarly, Favre and colleagues (2015), in a study carried out in an endemic area in Northeastern Brazil, noted that one year after treatment, the rate of reinfection was $21.6 \%$. In a more recent study, Favre and colleagues (2021) assessed the effect of educational actions among schoolchildren 
regarding commitment to diagnosis and treatment for schistosomiasis, as well as on knowledge of the disease. They observed that educational actions increased commitment in the schoolchildren and improved knowledge of the disease, confirming that these are important tools to enhance participation of schoolchildren in control campaigns.

About half the students stated that school is the main source of information on schistosomiasis. Although the theme "parasitic diseases" is part of the curriculum in science/biology, it does not seem to be sufficiently addressed in basic school education. In addition, the teaching material may contain inaccurate information for the target students. Furthermore, teachers may have difficulty in approaching this topic in their classes, due to lack of information, as well the absence of continuing education programs on public health. Therefore, PCE should develop actions to train and qualify teachers regarding the transmission forms and prevention methods of parasitic diseases. In addition, greater efforts should be made to inform the young population, preferably through various forms of media. This can help to reduce the number of new cases as it generates the scientific empowerment of students and, consequently, their families (Santos et al., 2012). The students rarely mentioned health and endemic agents, as well as the health unit itself. A few actions focused on the treatment of the disease had already been reported at the basic health unit in the village, according to information released by the city hall. These should act as important sources of information on schistosomiasis, especially in endemic areas, since they are permanently in touch with the population at risk and could assist in controlling the disease.

Several studies corroborate the link between poor basic sanitation and the occurrence of neglected diseases. High prevalence of SM has been reported in communities presenting economic and social vulnerability, poor housing and environmental infrastructure, as well as insufficient schooling (Rollemberg et al., 2011; Vidal et al., 2012; Martins-Melo et al., 2014; de Melo et al., 2014; Silva da Paz et al., 2021). In the 2010 census, only 28\% of the Lagarto households had adequate sewage collection. More importantly, there is no sewerage system in Jenipapo village (IBGE, 2019). The lack of basic sanitation maintains the transmission cycle of S. mansoni and, therefore, contributes to the high prevalence of schistosomiasis in this region. Regarding the government's role in fighting schistosomiasis, most students already knew that the state plays a fundamental role in reducing the number of cases of the disease, since it can promote public policies aimed at expanding the sewage network. Surprisingly, more than $1 / 3$ of the students believed that not accumulating standing water would be an effective measure in preventing schistosomiasis.

This study has some limitations that merit attention. Firstly, part of the participants in the pre-test chose not to continue in the study, probably signifying a source of bias. Unfortunately, when we applied the questionnaire 
in the post-test, one of the teachers did not authorize the application in his class, culminating in a sample loss. Secondly, it is possible that the students who opted not to continue in the study were the ones with worse pre-knowledge, while the ones that continued had higher pre-knowledge. Nevertheless, these potential limitations do not diminish the findings of the study. Yet the alarming data reported in the pre-test demonstrate the lack of knowledge regarding schistosomiasis in a highly endemic area.

This analysis corroborates the importance of educational actions with schoolchildren to expand their knowledge of schistosomiasis and help control the disease, especially in endemic areas. The results reported prior to the educational actions are worrying and showed a marked lack of knowledge of the disease in most students. Conversely, the data collected after the educational interventions indicated a significant increase in student knowledge, especially regarding the mode of transmission and prophylaxis of schistosomiasis. Fortunately, education can contribute decisively in raising student awareness of preventive methods and assisting parasitic disease control. However, it is necessary to emphasize that education alone is not enough to fight the disease. The control of schistosomiasis requires the implementation of integrated measures, such as improvement in environmental and home infrastructure, mainly in the supply of treated water and sanitary sewage, in the diagnosis and treatment of patients and by health education actions.

\section{CONFLICTING INTERESTS}

No conflict of interests is declared.

\section{REFERENCES}

1. Abera B, Alem G, Yimer M, Herrador Z. Epidemiology of soil-transmitted helminths, Schistosoma mansoni and haematocrit values among schoolchildren in Ethiopia. $J$ Infect Dev Ctries 7: 253-260, 2013.

2. Assefa A, Dejenie T, Tomass Z. Infection prevalence of Schistosoma mansoni and associated risk factors among schoolchildren in suburbs of Mekelle city, Tigray, Northern Ethiopia. Momona Ethiop J Sci 5: 174, 2013.

3. Barry M, Maguire JH, Weller PF. The American Society of Tropical Medicine and Hygiene initiative to stimulate educational programs to enhance medical expertise in tropical diseases. Am J Trop Med Hyg 61:681-688, 1999.

4. Bieri FA, Gray DJ, Raso G, Li YS, McManus DP. Review: A systematic review of preventive health educational videos targeting infectious diseases in schoolchildren. Am J Trop Med Hyg 87: 972-978, 2012.

5. Brasil. Ministério da Saúde. 2014. Vigilância da Esquistossomose mansoni: diretrizes técnicas. Available in:http://vigilancia.saude.mg.gov.br/index.php/download/vigilancia-daesquistossomose-mansoni-diretrizes-tecnicas/Accessed in: 6/2/21. 
6. Brasil. Ministério da Saúde. 2020. PCE - Programa de Controle da Esquistossomose - Sergipe. Available in:http://tabnet.datasus.gov.br/cgi/tabcgi.exe?sinan/pce/cnv/pcese.def Accessed in: $6 / 10 / 21$.

7. Costa CS, Rocha AM, da Silva GS, de Jesus RPFS, de Albuquerque AC. Programa de Controle da Esquistossomose: avaliação da implantação em três municípios da Zona da Mata de Pernambuco, Brasil. Saúde Debate 41: 229-241, 2017.

8. de Melo EV, da Costa W, Conceição MJ, Coura JR.A comparative cross-sectional study on the prevalence and morbidity of schistosomiasis in a community in northeastern Brazil (19792010). Mem Inst Oswaldo Cruz 109: 340-344, 2014.

9. do Amaral RS, Tauil PL, Lima DD, Engels D. An analysis of the impact of the Schistosomiasis Control Programme in Brazil. Mem Inst Oswaldo Cruz 101: 79-85, 2006.

10. dos Santos AD, Lima ACR, Santos MB, Alves JAB, Góes MAO, Nunes MAP, Souza-Sá SLC, Araújo KCGM. Spatial analysis for the identification of risk areas for schistosomiasis mansoni in the state of Sergipe, Brazil, 2005-2014. Rev Soc Bras Med Trop 49: 1-8, 2016.

11. Favre TC, Pieri OS, Barbosa CS, Beck L. Avaliação das ações de controle da esquistossomose implementadas entre 1977 e 1996 na área endêmica de Pernambuco, Brasil. Rev Soc Bras Med Trop 34: 569-576, 2001.

12. Favre TC, Massara CL, Beck LCNH, Cabello RKSA, Pieri OS. Adherence to diagnosis followed by selective treatment of schistosomiasis mansoni and related knowledge among schoolchildren in an endemic area of Minas Gerais, Brazil, prior to and after the implementation of educational actions. Parasite Epidemiol Control 13:e00208, 2021.

13. Favre TC, Pereira APB, Beck LCNH, Galvão AF, Pierre O. School-based and communitybased actions for scaling-up diagnosis and treatment of schistosomiasis toward its elimination in an endemic area of Brazil. Acta Trop 149:155-162, 2015.

14. Ferreira GR, Andrade CFS. Alguns aspectos socioeconômicos relacionados a parasitoses intestinais e avaliação de uma intervenção educativa em escolares de Estiva Gerbi, SP. Rev Soc Bras Med Trop 38: 402-405, 2005.

15. Gazzinelli A, Correa-Oliveira R, Yang GJ, Boatin BA, Kloos H. A research agenda for helminth diseases of humans: Social ecology, environmental determinants, and health systems. PLoS Negl Trop Dis 6: e1603, 2012.

16. Hassanin A, Kamel S, Waked I, Fort M. Egypt's ambitious strategy to eliminate hepatitis C virus: A case study. Glob Heal Sci Pract 9: 187-200, 2021.

17. IBGE. Instituto Brasileiro de Geografia e Estatística. 2019. Censo Demográfico de Lagarto. Brasil 1. Available in: https://cidades.ibge.gov.br/brasil/se/lagartoAccessed in: 2/4/21.

18. Katz N. Inquérito Nacional de Prevalência da Esquistossomose mansoni e Geo-helmintoses.1ed. CPqRR: Belo Horizonte, 2018. 76 p.

19. King CH, Kittur N, Binder S, Campbell CH, N'Goran EK, Meite A, Utzinger J, Olsen A, Magnussen P, Kinung'hi S, Fenwick A, Phillips AE, Gazzinelli-Guimaraes PH, Dhanani N, Ferro J, Karanja DMS, Mwinzi PNM, Montgomery SP, Wiegand RE, Secor WE, Hamidou AA, Garba A, Colley DG. Impact of Different Mass Drug Administration Strategies for Gaining and Sustaining Control of Schistosoma mansoni and Schistosoma haematobium Infection in Africa. Am J Trop Med Hyg 103: 14-23, 2020.

20. Lima TF. Análise da reinfecção pelo Schistosoma mansoni entre escolares com idade de 5 a 15 anos em área endêmica: Vale do Jequitinhonha - MG. Universidade Federal de Minas Gerais. Dissertação de Mestrado em Enfermagem. Repositório Digital UFMG: Belo Horizonte, 2015. $107 \mathrm{p}$.

21. Lima SVMA, dos Santos AD, Duque AM, de Oliveira Goes MA, da Silva Peixoto MV, da Conceição Araújo D, Ribeiro CJN, SantosMB, Araújo KCGM, Nunes MAP. Spatial and temporal analysis of tuberculosis in an area of social inequality in Northeast Brazil. $B M C$ Public Health 19: 1-9, 2019. 
22. Martins-Melo FR, Pinheiro MCC, Ramos AN, Alencar CH, Bezerra FSM, Heukelbach J. Trends in schistosomiasis-related mortality in Brazil, 2000-2011. Int J Parasitol 44: 10551062, 2014.

23. Nofal MR, Halim N, Le N, Sabin LL, Williams L, Bonawitz R, Nguyen HV, Nguyen TTT, Gill CJ. Unpacking the "Black Box": How an SMS-Based Continuing Medical Education Intervention Improved Medical Knowledge Among HIV Clinicians in Vietnam. Glob Health Sci Pract 6: 668-679, 2018.

24. Paixão MM, Ballouz T, Lindahl JF. Effect of education on improving knowledge and behavior for arboviral diseases: A systematic review and meta-analysis. Am J Trop Med Hyg 101: 441447, 2019.

25. Paz WS, Gomes DS, Ramos RES, Cirilo TM, Santos IGA, Ribeiro CJN, Araújo KCGM, Jesus AMR, Santos AD, Bezerra-Santos M. Spatiotemporal clusters of schistosomiasis mortality and association with social determinants of health in the Northeast region of Brazil (1980-2017). Acta Trop 212: 105668, 2020.

26. Rollemberg CVV, Santos CMB, Silva MMBL, Souza AMB, da Silva ÂM, de Almeida JAP, Jesus AR. Aspectos epidemiológicos e distribuição geográfica da esquistossomose e geo-helmintos, no estado de Sergipe, de acordo com os dados do programa de controle da esquistossomose. Rev Soc Bras Med Trop 44: 91-96, 2011.

27. Ruiz-Díaz MS, Mora-García GJ, Salguedo-Madrid GI, AlarioÁ, Gómez-Camargo DE. Analysis of health indicators in two rural communities on the Colombian Caribbean coast: Poor water supply and education level are associated with water-related diseases. Am J Trop Med Hyg 97:1378-1392, 2017.

28. Santos AD, Silva J, Lima AC, Santos M, Lima S, Amor M, Santos C, Vasconcelos A, Dolabella S, Araújo KCGM. Spatial analysis of the prevalence of schistosomiasis in an endemic coastal area in northeastern Brazil. Geospat Health 12: 360-368, $2017 \mathrm{a}$.

29. Santos MB, Oliveira M, Barreto AS, Pereira JM, Costa MCFS. Evaluation of knowledge about parasitosis and an educational intervention with students of a municipal school in Santana do Ipanema, state of Alagoas. Sci Plena 8: 1-7, 2012.

30. Santos MB, dos SantosAD, da Silva PP, Barreto AS, dos Santos EO, França AVC, Barbosa CS, Araújo KCGM. Spatial analysis of viral hepatitis and schistosomiasis coinfection in an endemic area in Northeastern Brazil. Rev Soc Bras Med Trop 50: 383-387, $2017 \mathrm{~b}$.

31. Santos MB, dos Santos AD, Barreto AS, Souza MR, Goes MADO, Barreto Alves JA, Barreto IDC, Silva JRS, Oliveira DT, Araújo KCGM, Duthie MS, Jesus AM. Clinical and epidemiological indicators and spatial analysis of leprosy cases in patients under 15 years old in an endemic area of Northeast Brazil: An ecological and time series study. BMJ Open 9: e023420, 2019.

32. Saucha CVV, Silva JAM, Amorim LB. Condições de saneamento básico em áreas hiperendêmicas para esquistossomose no estado de Pernambuco em 2012. Epidemiol Serv Saúde 24: 497-506, 2015.

33. Silva da Paz W, Duthie MS, de Jesus AR, de Araújo KCGM, dos Santos AD, Bezerra-Santos M. Population-based, spatiotemporal modeling of social risk factors and mortality from schistosomiasis in Brazil between 1999 and 2018. Acta Trop 218: 105897, 2021.

34. Vidal LM, Barbosa AS, Cardoso Ribeiro RM, Santana da Silva LW, Alves Vilela AB, Prado FO. 2012. Considerações Sobre Esquistossomose Mansônica No Município De Jequié, Bahia. Rev Patol Trop 40: 367-382, 2012.

35. WHO. World Health Organization. Schistosomiasis and soiltransmitted helminthiases: numbers of people treated in 2017. Wkly Epidemiol Rec 9: 681-692, 2018. 